\title{
Forest Soil Management: A Mexican Experience
}

\author{
Helena Cotler $^{1 *}$ (D) Leticia Merino², Sergio Martinez-Trinidad ${ }^{3}$ \\ ${ }^{1}$ Centro de Investigación en Ciencias de Información Geoespacial A.C., Mexico City, Mexico \\ ${ }^{2}$ Instituto de Investigaciones Sociales, Universidad Nacional Autónoma de México, Mexico City, Mexico \\ ${ }^{3}$ Colegio de Postgraduados-Puebla, Puebla, Mexico \\ Email: ^helena.cotler@gmail.co
}

How to cite this paper: Cotler, H., Merino, L. and Martinez-Trinidad, S. (2020) Forest Soil Management: A Mexican Experience. Open Journal of Soil Science, 10, 374-390. https://doi.org/10.4236/ojss.2020.109020

Received: July 28, 2020

Accepted: September 12, 2020

Published: September 15, 2020

Copyright $\odot 2020$ by author(s) and Scientific Research Publishing Inc. This work is licensed under the Creative Commons Attribution International License (CC BY 4.0).

http://creativecommons.org/licenses/by/4.0/ (c) (i) Open Access

\begin{abstract}
Forests improve the livelihoods and resilience of communities in diverse ways. In particular, soils provide important environmental services for communities in addition to performing many essential ecological functions in forest ecosystems, such as nutrient uptake, organic matter decomposition, water storage, and provision of anchorage for plant growth. The sound management of forest soils, although often disregarded, is a key element of sustainable forest management. From 2002 to 2016 the Forest Soil Conservation and Restoration Sub-Program was designed and implemented by the National Forest Commission (CONAFOR) in Mexico. Forests in Mexico have high biological diversity and are often owned, governed, and managed by communities or, in some cases, community forestry is practiced. Despite the importance of periodic monitoring to ensure that policies are both effective and suitable for diverse conditions and decision making, the policies implemented by this program were not evaluated during its years of operation. Therefore, in the present study, we aimed to identify the deficiencies of this policy as well as opportunities based on a review of the official information available on the Forest Soil Conservation and Restoration Sub-Program of CONAFOR during the 2002-2016 period and interviews with key informants. In addition, we aimed to highlight experiences that may be useful for similar soil conservation policies in tropical forest regions. The identified limitations ranged from conceptual problems such as policy weakness and lack of understanding of local drivers of soil degradation to an overly rigid implementation of soil conservation measures across diverse forest ecosystems and socio-ecological contexts. These deficiencies had several unintended outcomes: perhaps the most relevant was the inability of forest communities to build capacities for soil conservation. Another important limitation was the complete lack of monitoring of the program and its outcomes, which could have prevented its poor results. Finally, a lack of transparency in the distribution and determination of funding was noted. In conclusion, the hierarchical approach of this policy appears to have compromised its long-term efficacy.
\end{abstract}




\section{Keywords}

Soil Conservation, Soil Forest, Forest Communities, Soil Conservation Policy

\section{Introduction}

Forests provide many essential goods and environmental services that contribute to local well-being and livelihoods, such as food, firewood, shelter, fodder fiber, income, and employment in addition to sheltering biodiversity, sequestering carbon, and regulating the water cycle. For these reasons, forests are essential for the communities that live within and near them and for fostering ecosystem resilience at both the global and local level [1].

Soils are the foundation of forest ecosystems: they help to regulate important ecosystem processes, such as nutrient uptake, organic matter decomposition, and water storage in addition to providing anchorage for trees. The sound management of forest soil is thus a key element of forest conservation and sustainable forest management [2].

Soil conservation practices are classified as vegetative or mechanical. Both can reduce overland flow velocity and thereby slow sediment transport, resulting in sediment deposition [3] [4]. Vegetative practices function by adding organic matter to soils in order to improve their quality [5]. In contrast, mechanical practices are also commonly implemented but can also have some negative effects. For example, terracing can increase soil erosion and contribute to the formation of gullies, and the construction of ditches can lead to the deterioration of soil quality [6]. A combination of both types of practices adapted to local conditions is often best in order to effectively retain sediments and ensure the sustainability of soil conservation [3] [5].

Policy monitoring and assessment are key elements of adaptative policy management that are particularly important in the field of environmental and natural resources [7]. Despite their importance, almost all forest protection and restoration policies in Mexico up to date lack systematic monitoring, thereby missing important opportunities to learn from experience [8] [9]. From 2002 to 2016, the Forest Soil Conservation and Restoration Sub-Program (FSCRSP) of CONAFOR $^{1}$ operated as the most important soil conservation initiative in the history of Mexico, actively implementing different measures in most of Mexico's forest regions. Despite its potential, it was canceled in 2017.

Therefore, in the present paper, we aimed to evaluate the performance of the FSCRSP. Specifically, we aimed 1) to evaluate the coherence of soil conservation practices and budget allocation with the actual soil degradation problems and restoration needs of different regions, focusing on the transparency of resource use and concentration of administrative capacities; 2) to assess the program's ${ }^{1}$ The Forest Soil Conservation and Restoration Sub-Program forms part of the ProÁrbol program under which other sub-programs exist, including several oriented toward the control of forest pests and fires, planning, payments for environmental services, community forestry, and reforestation. 
flexibility and capacity to adapt to the diverse conditions of Mexico's forest regions and to contemplate the diverse drivers of deterioration; and, finally, 3) to highlight some critical lessons learned from this initiative that would be useful for improving forest soil conservation and restoration practices.

\section{Materials and Methods}

Like other cases of evaluations of other programs [7], our research was based on the review of the information gathered and/or produced from several sources by the federal government ${ }^{2}$.

1) The Operational Rules of the FSCRSP from 2002 to 2016 (CONAFOR, $2003,2007,2010,2012,2014,2017)$ were reviewed to examine changes in the premises of this policy in regard to the objectives of soil conservation and restoration and eligibility criteria.

2) The Manual on Protection, Restoration, and Soil Conservation [10] [11] [12] [13] was reviewed to extract information on the official forest soil conservation guidelines.

3) Soil Erosion Map of the National Institute of Statistics and Geography (Instituto Nacional de Estadística y Geografía [14], and INEGI's Series V land-use map [15] at a scale of 1:250,000 were reviewed to identify priority areas.

4) We also performed a budget analysis to examine the continuity and allocation of financial support considering the long time frame required for soil restoration. A period of seven consecutive years was considered as the threshold for continuous funding. Finally, external reviews of the program for 2002-2017 period were also reviewed [16] [17] [18]. These addressed environmental performances, efficiency of subsidies, and changes in soil conservation practices.

5) The results of the initial assessment of the continuity and allocation of financial support and soil conservation practices were also analyzed within the territorial context, grouping these findings per ecoregion of Mexico. We used the definition of ecoregion from the North American Commission for Environmental Cooperation. An ecoregion is understood as an area containing a geographically distinctive set of natural communities that share species, ecological dynamics, and environmental conditions. Notably, the ecoregional diversity of Mexico includes a broad diversity of soils (Figure 1 and Table 1 [19]).

The consideration of ecoregions allowed us to evaluate the adequacy of different types of conservation practices in diverse types of landscapes that reflect soil-forming factors.

6) Using information obtained through the Federal Institute for Access to Public Information and Data Protection (Instituto Federal de Acceso a la Información y Protección de Datos [IFAI]), we identified several vegetative and mechanical practices for soil conservation that were implemented by the FSCRSP

${ }^{2}$ The documentation corresponding with national, state, and municipal levels from 2003 to 2015 was requested and delivered through the Federal Instituto for Information Access (IFAI). More information on the program can be found at INFOMEX: https://www.infomex.org.mx/gobiernofederal/home.action (no. de folio 1616100031315). 


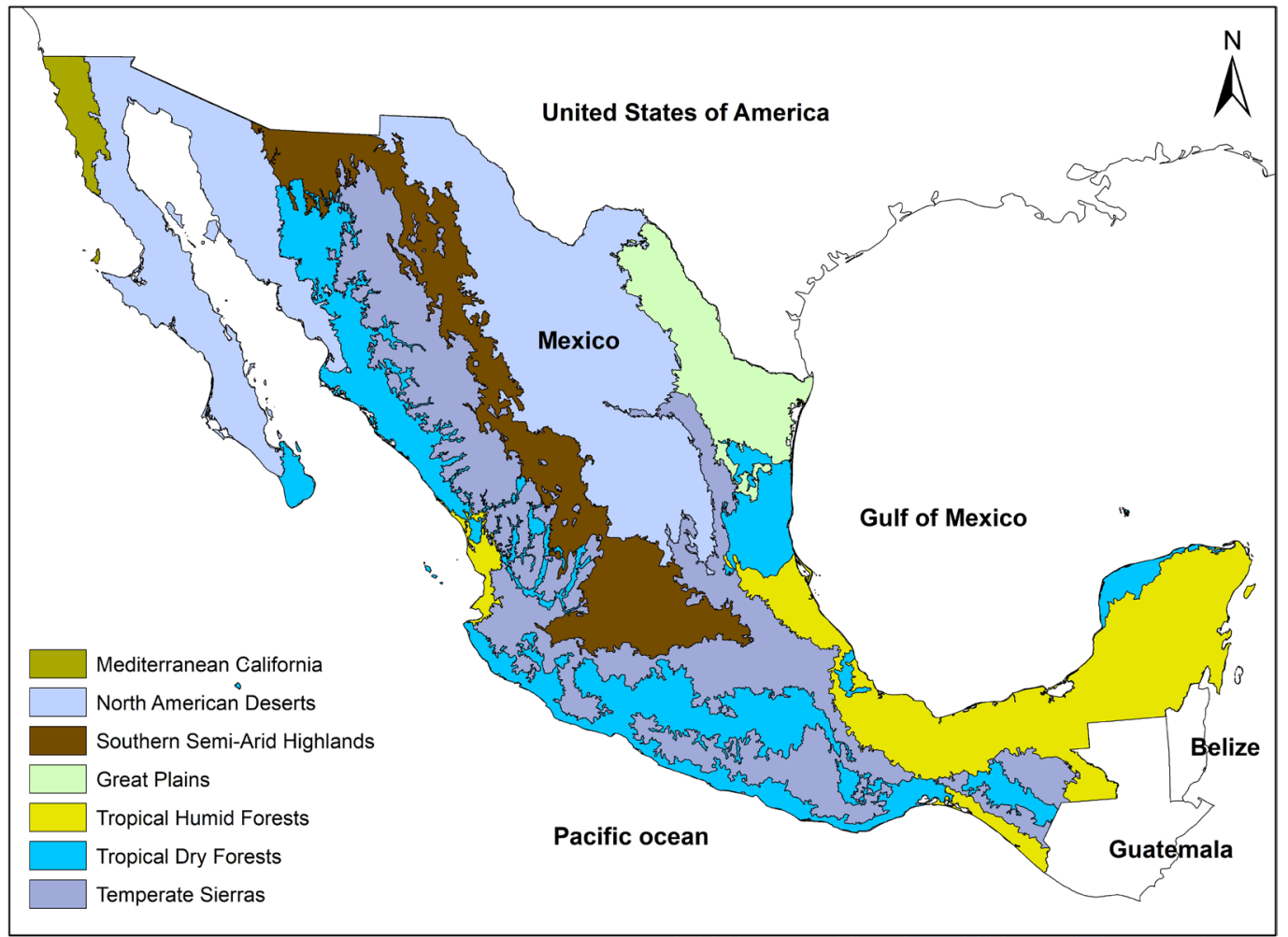

Figure 1. Terrestrial ecoregions of Mexico, level I [20].

Table 1. Main characteristics of Mexico’s terrestrial ecoregions.

\begin{tabular}{|c|c|c|c|}
\hline Ecoregion & State & Environmental Conditions & $\begin{array}{l}\text { Area }\left(\mathrm{km}^{2} \text { and } \% \text { of the }\right. \\
\text { country's territory) }\end{array}$ \\
\hline $\begin{array}{l}\text { North American } \\
\text { Deserts }\end{array}$ & Baja California, Baja California del Sur & $\begin{array}{l}\text { Arid climate with plains and Sierra mountains, forming } \\
\text { Calcisols, Leptosols, Regosols and Arenosols }\end{array}$ & $145,359(7.41)$ \\
\hline $\begin{array}{l}\text { Tropical Dry } \\
\text { Forests }\end{array}$ & Sonora, Tamaulipas & $\begin{array}{l}\text { Warm and semi-arid climate resulting from Sierra } \\
\text { mountains, plains and rolling hills, forming Leptosols, } \\
\text { Regosols, Phaeozems and Vertisols }\end{array}$ & $259,604(13.24)$ \\
\hline $\begin{array}{l}\text { Tropical Humid } \\
\text { Forests }\end{array}$ & $\begin{array}{l}\text { Campeche, Chiapas, Quintana Roo, } \\
\text { Tabasco, Veracruz, Yucatán }\end{array}$ & $\begin{array}{l}\text { Warm climate with a relief dominated by plains and rolling } \\
\text { hills, forming Leptosols, Luvisols, Vertisols and Phaeozems }\end{array}$ & $311,604(15.89)$ \\
\hline Temperate Sierras & $\begin{array}{l}\text { Colima, Chihuahua, Durango, Mexico } \\
\text { City, Michoacán, Morelos, Jalisco, } \\
\text { Nayarit, Oaxaca, Puebla, Sinaloa, } \\
\text { Guerrero, State of Mexico }\end{array}$ & $\begin{array}{l}\text { Semi-warm to semi-arid temperate climate resulting from } \\
\text { Sierra mountains and plateaus, forming Leptosols, Luvisols, } \\
\text { Regosols and Phaeozems }\end{array}$ & $820,027(41.81)$ \\
\hline $\begin{array}{l}\text { Southern } \\
\text { Semi-Arid } \\
\text { Highlands }\end{array}$ & $\begin{array}{l}\text { Tlaxcala, Hidalgo, San Luis Potosí, } \\
\text { Guanajuato, Querétaro, Aguascalientes, } \\
\text { Zacatecas, Nuevo León, Coahuila }\end{array}$ & $\begin{array}{l}\text { Mainly semi-arid to arid climate resulting from Sierra } \\
\text { mountains, rolling hills and plains, forming Leptosols, } \\
\text { Phaeozems and Vertisols }\end{array}$ & $424,891(21.66)$ \\
\hline
\end{tabular}

from 2002 to 2016 and classified them according to their conservation functions and characteristics, making note of the required materials and reproducibility (Table 2).

Interviews with key informants and experts were also carried out to understand and address different issues such as the participation of forest communities and the program's flexibility and capacity to adapt practices to specific 
Table 2. Types of soil conservation practices, functions, and characteristics implemented by the Soil Conservation and Restoration Sub-Program of CONAFOR, 2002-2017.

\begin{tabular}{|c|c|c|c|}
\hline Type of Practices & Soil Conservation Practices & Soil Conservation Functions & Characteristics \\
\hline $\begin{array}{l}\text { Mechanical } \\
\text { practices }\end{array}$ & $\begin{array}{l}\text { Dams, stone walls, contour } \\
\text { ditches, subsoiling, terraces, } \\
\text { contour bunding }\end{array}$ & $\begin{array}{l}\text { Reduce the velocity of concentrated } \\
\text { runoff, enhance the deposition of } \\
\text { sediments into ponds and behind check } \\
\text { dams [4] [3]. Contour ditches have a } \\
\text { negative impact on soil quality [6] [21]. }\end{array}$ & $\begin{array}{l}\text { Mechanical works require large economic } \\
\text { investments, machinery and engineering } \\
\text { knowledge. The implementation of this practice } \\
\text { tends to be hierarchical placing bureaucrats "in } \\
\text { the design chair at the top of the pyramid, and } \\
\text { the farmers, who are supposed to adopt these } \\
\text { designs at the base" [22]. } \\
\text { Extension agents are responsible for technology } \\
\text { transfer to communities that do have poor } \\
\text { capacities to replicate these practices } \\
\text { High cost and low short -term benefits [22]. }\end{array}$ \\
\hline $\begin{array}{l}\text { Vegetative } \\
\text { practices }\end{array}$ & $\begin{array}{l}\text { Use of dead plant material as soil } \\
\text { cover, living barriers, agroforestry } \\
\text { systems, promotion of secondary } \\
\text { vegetation (“acahual"), green } \\
\text { manure, windbreaks, living fences }\end{array}$ & $\begin{array}{l}\text { Reduce runoff rate, reduce overland flow } \\
\text { velocity, act as living filters, retain } \\
\text { sediments, increase soil organic matter } \\
\text { and improve soil fertility and quality[4] } \\
{[5][23] \text {. }}\end{array}$ & $\begin{array}{l}\text { Use of available, local material through } \\
\text { practices familiar to farmers [24]. } \\
\text { Farmers participate in technology design, } \\
\text { adapting it to local context; Medium cost with } \\
\text { regard to benefits obtained [22] }\end{array}$ \\
\hline
\end{tabular}

ecological conditions. Those interviewed were Juan Manuel Torres Rojo, former General Director of CONAFOR (2009-2012); Lucía Madrid Ramírez from the Civil Mexican Council for Sustainable Silviculture (Consejo Civil Mexicano para la Silvicultura Sostenible), Juan Manuel Frausto from the Mexican Fund for Nature Conservation (Fondo Mexicano de Conservación de la Naturaleza); and Fernando Rivera Valdez, a forest technician.

\section{Results}

CONAFOR, created in 2002, is responsible for promoting sustainable management and conservation practices in Mexico's forests. As a national agency, its rules and guidelines in regard to forest soils are used to guide public investment in different forest regions of the country. To access CONAFOR's resources, forest owners (mostly forest communities) must request them on a yearly basis. In the case of the FSCRSP, after funding was approved, $70 \%$ was delivered at the beginning of the intervention and $30 \%$ at the end.

Forest soil policy in Mexico was built on the paradigm that the main causes of forest deterioration are deforestation, land-use change, and overgrazing [25]. Whether this diagnosis applies to the forests of the different eco-regions of the country is an open question that requires further and urgent field research. From 2002 to 2016, the operational rules of the FSCRSP were modified several times (Figure 2) in response to the increasing importance given to soil conservation by CONAFOR. Institutionally, forest soils shifted from simply being a component of a training program on forest management to being the main focus of the office of Forest Soil Conservation and Restoration established in 2010 [26].

The objectives of both soil conservation and restoration were to implement "practices aiming to control soil degradation and maintain soil productivity." This understanding of conservation and restoration as synonymous compromised since 
2003

Conceptual focus
of the forest soil
conservation
program

Elegibility criteria

Soil conservation practices
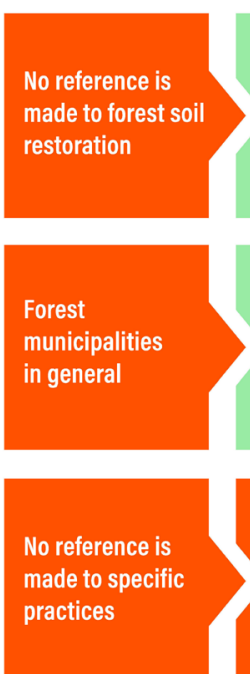

2007

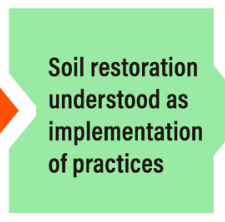

Forest communities with

severe to medium soil erosion

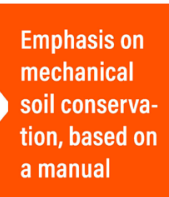

2012

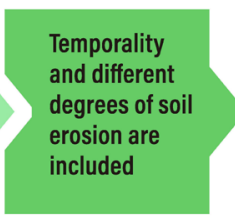

Watershed criterion: forests with different degrees of soil erosion

\section{New practices} introduced, including agroforestry systems and vegetative
2015

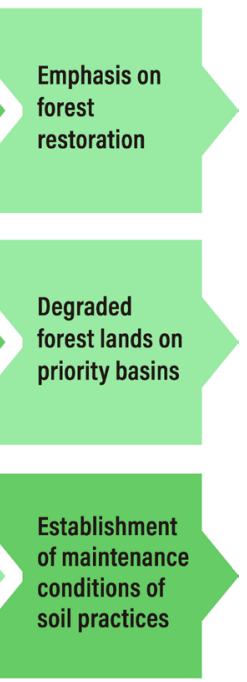

Figure 2. Changes to CONAFOR's forest soil conservation and restoration sub-program based on CONAFOR [10] [11] [13] [27].

the beginning the ability of the program to provide differentiated treatments tailored to differing levels of soil degradation and ecosystem health. No baselines, indicators, or monitoring methods for tracking the responses of soils to different interventions or their impacts on soil functions were ever defined. Emphasis was largely placed on mechanical measures (versus vegetative ones) and, specifically, on the control of soil erosion and retention of sediments. It was only in 2016 when the recovery of soils' capacity to provide environmental goods and services began to be mentioned.

In the initial selection of municipalities, the program aimed to strengthen forest management capacities without focusing on soil conservation. From the start, a distinction was made between practices oriented toward hillsides and those toward rills control, sediment retention, and water harvesting for reforestation. Local participation was limited to the implementation of the practices already included in CONAFOR's Manual on Soil Protection, Restoration, and Conservation, with little room for local initiatives. Nevertheless, by 2012, ten years after its creation, important improvements were made: The operational rules were updated to incorporate diverse vegetative practices, such as agroforestry, with specific recommendations for some regions, such as the Yucatán Peninsula in the Tropical Humid Forests ecoregion. The criteria of maintenance of soil restoration practices over several years were also introduced.

In 2016, CONAFOR's budget was reduced by $40 \%$, leading to the closure of various programs and offices, including the Soil Management Department. In 2017, the FSCRSP became a component of the Forest Restoration Program. The loss of the soil program's staff and status within CONAFOR meant the loss of institutional capacities to monitor the impacts of soil restoration and conservation practices, to integrate new knowledge into these practices, and to adapt them to local contexts. 


\subsection{Budget}

Between 2003 and 2015, the budget devoted to forest soil conservation and restoration increased substantially yet was very unequally distributed in geographical and thematic terms (Figure 2), lacking clear allocation criteria. From 2003 to 2006, the program's budget fluctuated between $1,355,913$ and 2,713,079 USD ${ }^{3}$. From 2007 to 2008, it increased by 483\%, yet decreased once again in 2009 followed by an increase from 2010 to 2012 . Notably, the budget dramatically increased in 2013, reaching a maximum of 26,659,287 USD, which represented an increase of nearly $2000 \%$ with respect to the original budget. From 2006 to 2012, forest and soil restoration programs were actually the best funded programs of CONAFOR, with almost $50 \%$ of the total budget being allocated to this area [28].

Resources allocated to mechanical practices were much higher than those invested in vegetative ones. During the 2007-2008 period, less than $4 \%$ of the total program's budget was devoted to vegetative practices. In 2013, this proportion increased to $18 \%$ and, once again, to $26 \%$ in 2014-2015 (Figure 3). As shown below, this budget trend was accompanied by the diversification of the vegetative practices supported by the program.

Since 2007, the rules of the FSCRSP incorporated diverse criteria related to environmental conditions affecting the level of soil erosion with the aim of focusing on the most eroded areas. According to the National Erosion Assessment, the Temperate Sierras are the ecoregion with the most severe forest soil erosion in Mexico followed by the Southern Semi-Arid Highlands, the North American Deserts, and Tropical Dry Forests (Figure 4).

Between 2003 and 2015, the budget of the program focused on the states of Durango, Chihuahua, and Guerrero (Temperate Sierras) as well as Sonora (Dry

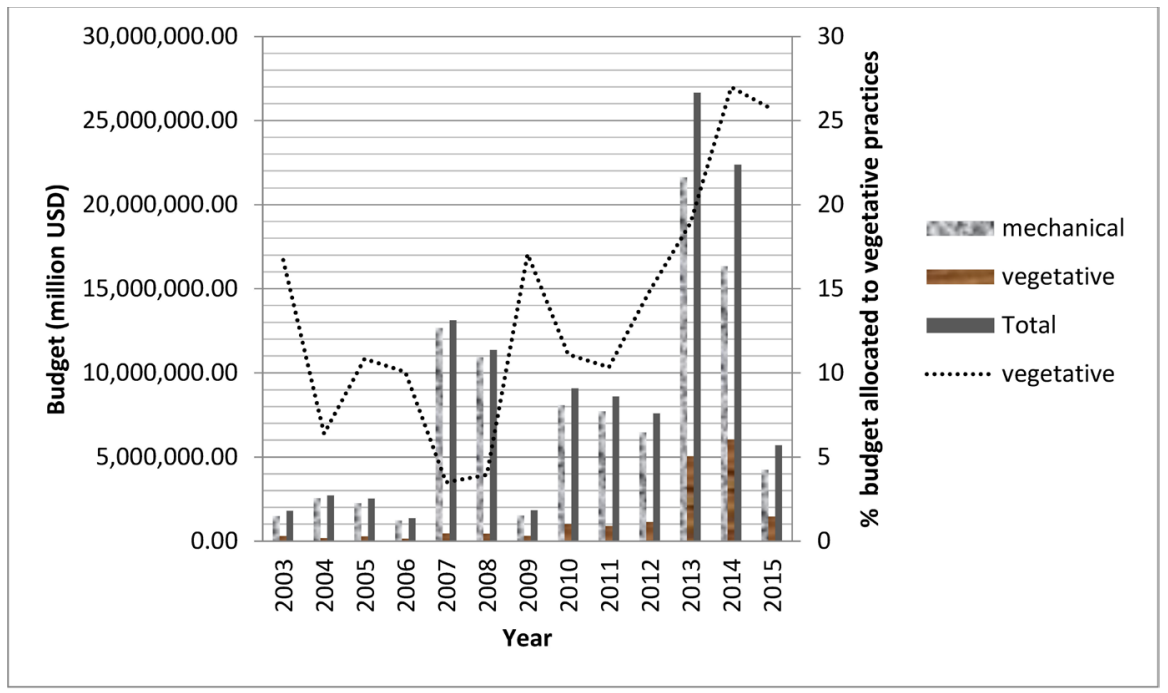

Figure 3. Budget allocated to vegetative and mechanical practices by CONAFOR Forest Soil Conservation and Restoration Sub-Program from 2003 to 2015.

${ }^{3}$ Mexican peso to U.S. dollar exchange rate: 19.45 (25 February 2020). 
Tropical Forests) and Guanajuato (Southern Semi-Arid Highlands) followed by Veracruz and Chiapas (Tropical Forests). Despite the large extension of forest in Durango and Chihuahua, only a small number of forest owners in these states benefited from the program's funds [17]. There was an important concentration of funds in only a few municipalities, such as Hermosillo, which received $7.3 \%$ of the program's total budget between 2003 and 2007 [17].

However, in terms of resources invested per square kilometer, the states most affected by soil erosion (Durango, Chihuahua, and Guerrero) only received between 0.4 and 2.2 USD per $\mathrm{km}^{2}$, whereas those with reduced soil erosion problems such as Colima, Mexico City, Morelos, Tlaxcala, and Aguascalientes respectively received $15.9,30,17.6,15$, and $11.1 \mathrm{USD} / \mathrm{km}^{2}$ (Figure 4 ). In this regard, the program operated with a complete lack of transparency, and the economic, social, or ecological criteria that guided the distribution of the budget were never clear [28].

\subsection{Forest Soil Conservation Activities}

As previously mentioned, the program mainly promoted mechanical practices such as the construction of dams, stone walls, and ditches in the ecoregions where it operated (Table 3; [16] [30]). In the driest regions of Mexico, 85\% of the cumulative budget was devoted to mechanical practices. This tendency was strongest in the North American Deserts, where 95\% of the total budget was devoted to these practices. Meanwhile, in the Temperate Sierras and Tropical Humid Forests, a lesser but still majority portion of the budget ( $83 \%$ and $63 \%$, respectively), was dedicated to mechanical practices (Figure 5).

The program's agenda and implementation were strongly centralized and hierarchical. Aside from working with a pre-established set of soil conservation practices for all of Mexico, the CONAFOR headquarters also rigidly defined the payments for the supported activities regardless of differing economic conditions throughout the country [12].

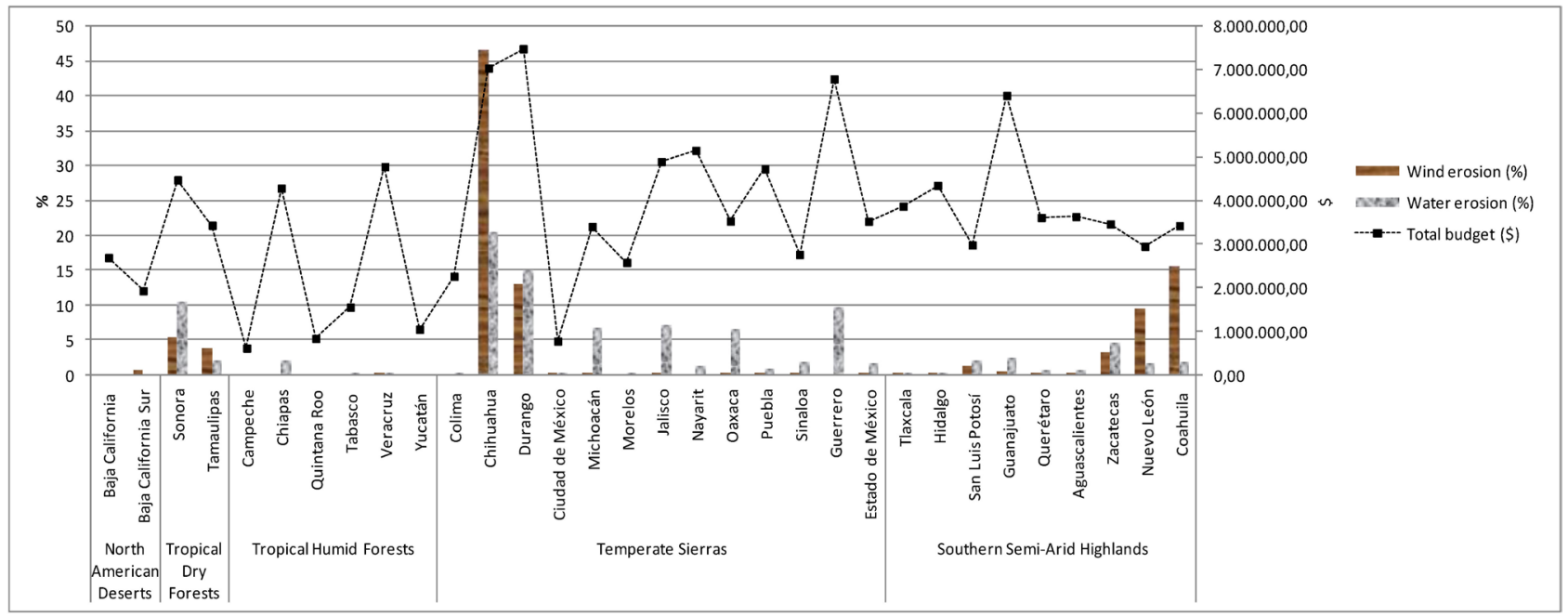

Figure 4. Forest soil erosion and forest soil conservation and restoration resources by state and ecoregion. Sources: [14] [29]. 


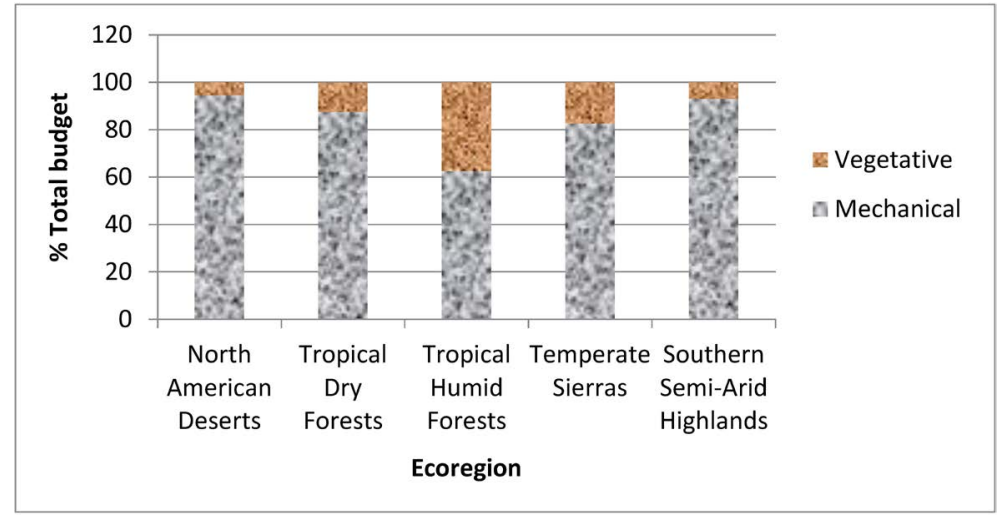

Figure 5. Soil conservation practices funded under the forest soil conservation and restoration sub-program per level I ecoregion of Mexico, level I.

Table 3. Main soil conservation practices funded by the Forest Soil Conservation and Restoration Sub-Program per ecoregion.

\begin{tabular}{ll}
\hline Ecoregion & Dominant Practices \\
\hline $\begin{array}{l}\text { North American } \\
\text { Deserts }\end{array}$ & $\begin{array}{l}\text { Dams, stone walls, ditches. From 2012, dams no longer dominate and practices } \\
\text { are diversified, with contour bunding and the use of dead plant material as soil } \\
\text { cover. }\end{array}$ \\
Tropical Dry & Contour bunding, ditches, terraces, stone walls. From 2011, they are used in \\
Forests & $\begin{array}{l}\text { conjunction with other practices: the use of dead plant material as soil cover and } \\
\text { living barriers. }\end{array}$ \\
Tropical Humid & $\begin{array}{l}\text { Agroforestry systems, acahuales, living terraces, living barriers, green manure, } \\
\text { Forests }\end{array}$ \\
windbreaks, living fences. In the first years (until 2010-2012), dams and ditches \\
were mainly constructed; they were gradually completed with terraces with a soil \\
cover of dead plants and agroforestry systems. \\
$\begin{array}{l}\text { Temperate } \\
\text { Sierras }\end{array}$ \\
$\begin{array}{l}\text { Dams, ditches, terraces, stone walls and use of dead plant material as soil cover. } \\
\text { In the first years (until 2011), the construction of dams dominated. Then, ditches } \\
\text { and stone walls were mostly constructed and used in conjunction with dead plant } \\
\text { material as soil cover. }\end{array}$ \\
$\begin{array}{l}\text { Dams, ditches, terraces, stone walls, contour bunding. In 2011, the construction } \\
\text { of dams no longer dominates and is replaced by ditches, stone walls, use of dead } \\
\text { plant material as soil cover and, occasionally, subsoiling. }\end{array}$ \\
\hline
\end{tabular}

The FSCRSP was designed to be implemented based on the Forest Soil Protection, Restoration, and Conservation manual wherein different practices and activities are described. However, there is no mention of the ecological and social criteria needed to guide the selection of these practices. Four editions of the manual were published: The first three versions proposed the same practices, and only one in five was a vegetative practice. The final edition of the manual introduced some drought mitigation measures, although these were only mechanical, and a new vegetative activity. As mentioned, the construction of dams and ditches largely dominated across all ecoregions.

\subsection{Soil Conservation: What Time Frame Is Necessary?}

Soil conservation and restoration are medium-to long-term processes. In this 
regard, the continuity of funding becomes particularly relevant. Considering seven consecutive years (half of the duration of the program) as a minimum period, the number of municipalities that received continuous support was very small: Only 16 of the 295 of municipalities where the program operated (5.4\%) received funding for this time period (Figure 6). Seven are located in the Tropical Humid Forests ecoregion, seven in the Temperate Sierras, and two in North American Deserts. In most of the municipalities and ecoregions, funding was discontinuous.

\section{Discussion}

To address the degradation of forest soils, the FSCRSP focused on the areas of Mexico with the most erosion. However, because of their low productivity, these regions are also the least attractive and least utilized by members of ejidos and communities [30]. Notably, external evaluations found that without the program's support [30], no actions would have been undertaken to protect and/or restore these soils by landowners [17] [30]. These results led us to two open questions: To what extent does the use of resources in the most eroded forest areas correspond with landowners' intent to restore? and, is the concentration of resources in the most degraded areas the most efficient or effective means of distributing resources?

Soil erosion is a complex, dynamic, multicausal, and local process. Two soil parameters governing soil productivity, soil organic matter and soil porosity, are the most likely to be impacted by forest management and use [9] [8]. It is also worth mentioning that these soil properties are only improved through vegetative practices, which are paradoxically the least funded by the program. It thus seems that, in the absence of a comprehensive perspective of local contexts and problems, the FSCRSP promoted mechanical solutions in most cases. The proposed options were limited and pre-defined with a poor capacity to respond to the wide heterogeneity of socio-ecological conditions and drivers of erosion in Mexico's forest regions.

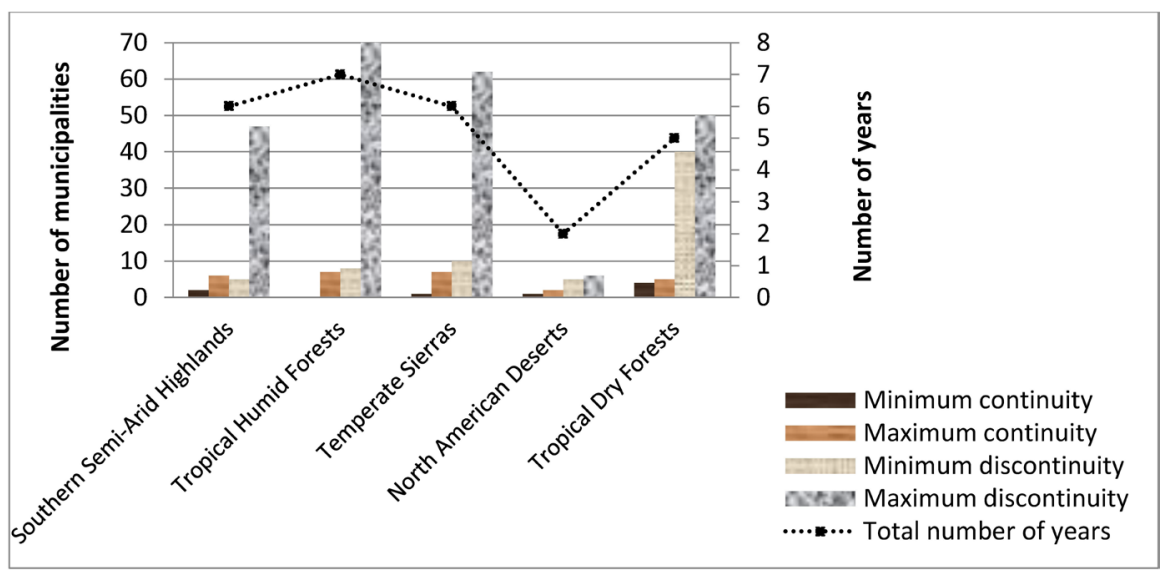

Figure 6. Continuity of funding from the Forest Soil Conservation and Restoration Sub-Program per ecoregion. 
Even so, in realm of the soil conservation, no conservation practice is a panacea that can be successfully adopted everywhere [3] [5]. The selection of soil conservation practices should therefore fully consider the particular social, environmental, and institutional conditions of each site [5] [6] in addition to the objectives of landowners, users, and managers. It is necessary to be fully aware of local interests, perceptions, and incentives in addition to the local histories of forest soil management that have led to degradation.

Despite the recommendations of several external evaluations, the program's approach remained rigid [17] [18] [30]. During the last ten years of its operation, the experience gained in each state and ecoregion was rarely incorporated into the program's manual. Another analysis [6] was able to influence the program's operational rules [12], although to only a limited extent ${ }^{4}$. The difficulty of modifying the inappropriate practices of such a program appears to be closely related to overly hierarchical and centralized administration [31].

The restriction of soil conservation activities to the rigid guidelines of a single manual also ignores the rich local knowledge of forest soil conservation, impeding communities' ownership of restoration initiatives. Furthermore, the hierarchical transfer of technology from expert technicians to local forest users characteristic of the FSCRSP largely paralyzed communities' capacity building. The outcomes of such programs appear to have an even greater negative impact on soil conservation in countries with highly biodiverse forests, which are largely owned by local communities [32] [33]. In these forests, local participation and knowledge are critical for sustainability.

Over the fourteen years of the program's operation, forest owners rarely reproduced mechanical soil conservation practices [6] [30]. On the other hand, this approach did initially result in a uniform policy, although slight changes were made later on with respect to the type of soil conservation practices implemented in some ecoregions. Mechanical measures were largely preferred as they are easier to report as an indicator of programmatic performance. However, they can also be a means of diverting resources and, unfortunately, a corrupt use of public funding (interview Juan Manuel Torres Rojo). It is also notable that close and continual advisory to local communities was absent, even though other CONAFOR programs clearly had local technicians working with communities on a permanent basis, particularly in regard to land use planning, which did result in the strengthening of communities' technical and governance capacities (interviews Lucia Madrid, Juan Manuel Frausto).

Also, as previously mentioned, restoration of forest ecosystems is a complex, long-term process rather than a single event or events. Any initial treatments are simply the first steps of this process [8]. Restoration can be a multi-year or even a multi-decade goal requiring the continual improvement of ecological conditions [8]. However, the FSCRSP only granted annual subsidies, a practice in-

${ }^{4}$ The discussion of the negative impact of ditches on soil quality was discussed with CONAFOR officials [6] [21]. As a result, the operational rules were modified in 2015, and this practice was prohibited along the Trans-Mexican Volcanic Belt. 
compatible with the long-time objectives of forest soil restoration and conservation. These goals require at least a medium-term vision based on participatory land-use planning. Continuity of funding should not only be based on the diagnosis of the state of ecosystems but also, according to [34] on communities "governance capacities" and "the development of trust and a sense of mutual obligation toward protecting the long-term sustainability of the resource". The duration of a program's financial support should be based on careful and continuous monitoring.

Another disregarded risk was related to the use of economic incentives. As in the case of other government programs that rely on the use of subsidies to promote desired behaviors, farmers may lose interest and abandon conservation practices when incentives end. This is particularly true when the problem, as is often the case with forest soil degradation, is not perceived as a top priority by community members.

Furthermore, the analysis clearly shows that the centralized policies of the FSCRSP were mostly unable to incorporate local views, values, opinions, and rules, preventing a comprehensive perspective of soil degradation and its processes. As a result, more often than not, technocratic solutions were proposed. On the other hand, adaptive governance is based on the consideration of broader contextual, social, and institutional processes, with emphasis on social learning and co-management. In the context of the severity of the current socio-ecological crises and frequent policy failures, it is critical to re-examine how governance and institutions operate in societies and whether top-down policies are effective. The complexity and uncertainty inherent to socio-environmental systems requires that policies be designed, implemented, and adapted according to the local context in order to solve problems and also create learning opportunities. In the present case, this implies the need to assess the ecological effects and economic efficiency of current forest and soil policies in Mexico.

The overarching purpose of environmental policy is to improve environmental conditions. However, despite growing environmental problems, financial resources are increasingly scarce. Accordingly, evaluation should also be a central component of environmental policy, especially to identify which policies are efficient and which have unexpected negative outcomes [7]. International research has provided a strong basis for best management practices (BMPs) in the monitoring of soil conditions and implementation of soil conservation and restoration measures. Effective soil monitoring relies on visual and quantitative soil disturbance indicators and soil quality indicators to assess the efficacy of BMPs under different conditions, including whether they contribute to maintaining soil and hydrologic functions [35].

Internationally, soil conservation programs contemplating the variability of local contexts have recurred to different methods and strategies such as soil monitoring protocols [36]; the development of distinct intervention strategies for different regions [37]; the definition of general principles to guide restoration 
practices, allowing forest owners to adapt them to local conditions [38]; different approaches for effective monitoring [8]; and the establishment of long-term research sites for producing information to adapt program parameters and report outcomes on a broader scale [2]. These strategies recognize and underline the importance of local approaches that are attentive to site context and markedly contrast with the natural resource management strategies of the Mexican government characterized by strongly centralized and hierarchical decision making. Policies driven under this approach are opposite to the decentralized, adaptive, bottom-up, and cooperative actions currently evidenced to be effective in ecosystem management [39].

Several factors contribute to the complexity of the assessment of soil conservation practices in forests, such as the heterogeneity of landscapes. Also, the outcomes of chosen measures are often uncertain, and impacts may be only visible in the long term. Furthermore, climate change exacerbates deterioration processes. However, the absence of monitoring of the ecological impacts in addition to the constraints of overly centralized institutional functioning undermines adaptive policy learning.

\section{Conclusions}

The Forest Soil Conservation and Restoration Sub-Program (FSCRPS) of CONAFOR for promoting soil conservation and restoration in Mexico failed to consider relevant contextual differences in forest regions and lacked a diagnosis of forest soil degradation processes. Besides, the forest communities' interests, visions, and norms in which measures were to be implemented were ignored.

The program mainly promoted rigid alternatives and solutions and largely failed to address the various deterioration drivers present in the different ecoregions, states, and municipalities of Mexico.

The present study highlights the unintended outcomes of a centralized soil conservation policy dominated by bureaucratic interests: more than $70 \%$ of the total budget was used to implement mechanical measures, such as the construction of dams, stone walls, and ditches, and these solutions were homogeneously implemented across all ecoregions, creating obstacles for the building of local capacities and, ultimately, contributing little to the improvement of forest soil quality in terms of organic matter and [8] [9]. The implementation of mechanical practices often favored rent-seeking practices.

The arbitrary and careless use of public resources is further evident in the pronounced lack of coherence in the allocation of financial resources, for example, 1) the unequal distribution of funding per $\mathrm{km}^{2}$ in the different ecoregions; 2) the concentration of funding in very few municipalities, specifically in an urban municipality; and 3) the lack of continuity of funding in most areas where the program operated.

Soil conservation is a long-term process with internationally documented experiences of both failures and successes [40] [41]. However, given the severity of 
soil degradation in Mexico and worldwide, it is necessary to shorten the learning curve of public policies through systematic assessments of soil conservation strategies from both environmental and social perspectives. Among the lessons learned from the FSCRSP are the following: First, it is necessary for soil conservation programs to be based on a careful analysis of the underlying drivers of land degradation and strong community governance, with forest owners actively taking part in the design, implementation, and monitoring of interventions in order to successfully achieve adaptive forest management. Second, the best soil management flexibly adapts to local conditions. Also, in this regard, one of the best indicators of the effectiveness of soil conservation practices is their degree of adoption by local communities. Third, to ensure the sustainability of soil, it is important to strengthen vegetative measures and not just mechanical ones. Third, it is important to establish global or regional monitoring protocols to identify the best forest soil conservation practices and adapt them to the research capabilities and local institutions involved in forest management in particular countries. Monitoring programs are essential for evaluating the efficiency of forest restoration efforts and mitigating the negative effects of poorly planned activities before they have long-term consequences, thereby enabling learning from experience [8].

Although the monitoring and assessment of land degradation has been widely discussed [42], these concepts are rarely included in policy design and implementation [43]. Despite an abundant research body on land degradation control, progress has been hampered by the lack of effective monitoring and assessment, not only of the state of the land but also of the performance and impacts of the interventions.

\section{Acknowledgements}

The authors acknowledge the comments of M. Claudia Lorena Galindo and Dr. José María León on an earlier draft of the manuscript. Dr. Juan Manuel Torres (CIDE, ex-CONAFOR), Mtra. Lucia Madrid (CCMS), Tech. Fernando Rivera Váldez and Ing. Juan Manuel Frausto (FMCN) for taking the time to share their knowledge about the design and implementation of the Forest Soil Conservation and Restoration subprogram. Gabriela Quiroz kindly designed Figure 2. Dr. Sergio Martínez-Trinidad thanks Dr. Jorge D. Etchevers Barra for support during his research stay at the Colegio de Postgraduados' Pedology Department. This research did not receive any specific grant from funding agencies in the public, commercial, or not-for-profit sectors.

\section{Conflicts of Interest}

The authors declare no conflicts of interest regarding the publication of this paper.

\section{References}

[1] FAO (2016) State of the World's Forests. Forests and Agriculture: Land-Use Chal- 
lenges and Opportunities. Food and Agriculture Organization of the United Nations, Rome. http://www.fao.org/3/a-i5588e.pdf

[2] Cline, R.C., Ragus, J., Hogan, G.D., Maynard, D.G., Foster, N.W., Terry, T.A., Heninger, R.L., Campbell, R.G. and Carter, M.C. (2006) Policies and Practices to Sustain Soil Productivity: Perspectives from the Public and Private Sectors. Canadian Journal of Forest Research, 36, 615-625. https://doi.org/10.1139/x05-266

[3] Hudson, N.W. (1987) Soil and Water Conservation in Semi-Arid Areas. FAO Land and Water Development Division. Food and Agriculture Organization of the United Nations, Rome. http://www.fao.org/docrep/t0321e/t0321e00.htm\#TopOfPage

[4] Mekonnen, M., Keestra, S.D., Stroosnijder, L., Baartman, J.E.M., Maroulis, J. (2015) Soil Conservation through Sediment Trapping: A Review. Land Degradation \& Development, 26, 544-556. https://doi.org/10.1002/ldr.2308

[5] Lal, R. (2014) Soil Conservation and Ecosystem Services. International Soil and Water Conservation Research, 2, 36-47. https://doi.org/10.1016/S2095-6339(15)30021-6

[6] Cotler, H., Cram, S., Martínez-Trinidad, S. and Quintanar, E. (2013) Forest Soil Conservation in Central Mexico: An Interdisciplinary Assessment. CATENA, 104, 280-287. https://doi.org/10.1016/j.catena.2012.12.005

[7] Bennear, L.S. and Coglianese, C. (2005) Measuring Progress: Program Evaluation of Environmental Policies. Environment: Science and Policy for Sustainable Development, 47, 22-39. https://doi.org/10.3200/ENVT.47.2.22-39

[8] DeLuca, T.H., Aplet, G.H., Wilmer, B. and Burchfield, J. (2010) The Unknown Trajectory of Forest Restoration: A Call for Ecosystem Monitoring. Journal of Forestry, 108, 288-295.

[9] Burger, J.A. and Kelting, D.L. (1999) Using Soil Quality Indicators to Assess Forest Stand Management. Forest Ecology and Management, 122, 155-166. https://doi.org/10.1016/S0378-1127(99)00039-0

[10] CONAFOR (2003) Reglas de operación para el otorgamiento de apoyos del Programa para el Desarrollo Forestal (PRODEFOR). Comisión Nacional Forestal, México. http://www.ccmss.org.mx/wp-content/uploads/2014/09/roprodefor.pdf

[11] CONAFOR (2007) Reglas de operación del Programa Pro-Árbol. Comisión Nacional Forestal, México.

http://www.ccmss.org.mx/wp-content/uploads/2014/10/convocatoria_pro_arbol_20 07.pdf

[12] CONAFOR (2014) Reglas de operación del Programa Nacional Forestal 2015. Comisión Nacional Forestal, México. http://www.conafor.gob.mx/apoyos/index.php/inicio/download/4005

[13] CONAFOR (2017) Reglas de operación de PRONAFOR. Comisión Nacional Forestal, México. http://dof.gob.mx/nota_to_doc.php\%3Fcodnota\%3D5467941

[14] INEGI (2014) Conjunto de datos de erosión de suelos, Serie I. Instituto Nacional de Estadística y Geografía, México.

https://www.inegi.org.mx/contenidos/temas/mapas/edafologia/metadatos/dicc_eros ion.pdf

[15] INEGI (2014) Guía para la interpretación de cartografía de uso del suelo y vegetación: Escala 1:250,000, serie V. Instituto Nacional de Estadística y Geografía, México. http://www.inegi.org.mx/geo/contenidos/recnat/usosuelo/Default.aspx

[16] Magaña, O. (2007) Evaluación externa de los apoyos de reforestación, obras y 
prácticas de conservación de suelos y sanidad forestal. Universidad Autónoma de Chapingo y Grupo GSP, Mexico.

[17] Valtierra, E., Magaña, O., Ojeda, E. and Sepulveda, J. (2008) Restauración de suelos forestales. Evaluación externa, ejercicio fiscal 2007. Colegio de Postgraduados, CONAFOR-SEMARNAT.

[18] Vargas, E. (2010) Informe de evaluación externa de los apoyos de restauración de suelos forestales. Ejercicio fiscal 2009. Universidad Autónoma Chapingo, Centro de Educación Continua, SEMARNAT-CONAFOR.

[19] Krasilnikov, P., Gutiérrez-Castorena, M.C., Ahrens, R.J., Cruz-Gaistardo, C.O., Sedov, S. and Solleiro-Rebolledo, E. (2013) The Soils of Mexico. Springer, Netherlands. https://doi.org/10.1007/978-94-007-5660-1

[20] Challenger A. and Soberón J. (2008) Los ecosistemas terrestres. In: CONABIO, Ed., Capital Natural de México, México, 87-108.

[21] Cotler, H., Cram, S., Martínez-Trinidad, S. and Bunge, V. (2015) Evaluación de prácticas de conservación de suelos forestales en México: Caso de las zanjas trinchera. Investigaciones Geográficas, 88, 6-18.

[22] Biot, Y., Blaikie, P.M., Jackson, C. and Palmer-Jones, R. (1995) Rethinking Land Degradation in Developing Countries. World Bank Discussion Paper 289, Washington DC, 94 p. https://doi.org/10.1596/0-8213-3329-1

[23] Castaño, J., Meulenberg, M.T.G. and Van Tilburg, A. (2002) A New Method of Measuring the Adoption of Soils Conservation Practices: Theory and Applications. Netherlands Journal of Agricultural Science, 50, 95-114. https://doi.org/10.1016/S1573-5214(02)80006-9

[24] Moreno C.A., Casas, A., Toledo, V.M. and Vallejo, M. (2016) Etnoagroforestería en México. Universidad Nacional Autónoma de México, México, 348 p.

[25] CONAFOR (2014) Programa Nacional Forestal 2014-2018. Comisión Nacional Forestal, México.

http://www.dof.gob.mx/nota_detalle.php? codigo $=5342551 \&$ fecha $=29 / 04 / 2014$

[26] CONAFOR (2010) Estrategia de conservación y restauración de suelos forestales a corto, mediano y largo plazo. Comisión Nacional Forestal, México.

[27] CONAFOR (2012) Criterios técnicos para la ejecución de proyectos de conservación y restauración de suelos. Comisión Nacional Forestal, México.

http://www.conafor.gob.mx/apoyos/docs/adjuntos/8afff80b7762272f5a0e0da39ba49 b31.pdf

[28] Zúñiga, I. and Deschamps, P. (2013) Políticas y subsidios forestales en México. Consejo Civil Mexicano para la Silvicultura Sostenible, México. http://www.ccmss.org.mx/descargas/CCMSS_Subsidios_Forestales_190513.pdf

[29] SEMARNAT-Colegio de Postgraduados (2002) Evaluación de la degradación del suelo causada por el hombre en la República Mexicana, escala 1: 250,000. SEMARNAT-Colegio de Postgraduados, México.

[30] Vargas, E. (2014) Informe final de resultados de monitoreo y evaluación complementaria de los apoyos de reforestación y suelos 2012. CONAFOR-SEMARNAT.

[31] Xu, J., Yin, R., Li, Z. and Liu, C. (2006) China's Ecological Rehabilitation: Unprecedent Efforts, Dramatic Impacts and Requisite Policies. Ecological Economics, 57, 595-607. https://doi.org/10.1016/j.ecolecon.2005.05.008

[32] Bray, D.B. and Merino-Pérez, L. (2005) La experiencia de las comunidades forestales en México. Secretaría de Medio Ambiente y Recursos Naturales, Instituto Nacional de Ecología, Consejo Civil Mexicano para la Silvicultura Sostenible A.C. 
Fundación Ford, México.

[33] Bray, D.B., Merino-Pérez, L. and Barry, D. (2006) The Community Forests of Mexico: Managing for Sustainable Landscapes. University of Texas Press, Austin.

[34] Nelson, R., Howden, M. and Smith, M.S. (2008) Using Adaptive Governance to Rethink the Way Science Supports Australian Drought Policy. Environmental Science \& Policy, 11, 588-601. https://doi.org/10.1016/j.envsci.2008.06.005

[35] Page-Dumroese D., Neary, D. and Trettin C. (2010) Scientific Background for Soil Monitoring on National Forests and Rangelands. Workshop Proceedings, Denver, 29-30 April 2008, 126 p.

[36] Curran, M., Dubé, S., Bulmer, C., Berch, S., Chapman, B., Hope, G., Currie, S., Courtin, P. and Kranabetter, M. (2009) Protocol for Soil Resource Stewardship Monitoring: Cutblock Level. Forest and Range Evaluation Program, B.C. Min. For. Ran. and B.C. Min. Env., Victoria, BC.

https://www2.gov.bc.ca/assets/gov/farming-natural-resources-and-industry/forestry /frep/frep-docs/indicators-soils-protocol.pdf

[37] Neary, D.G., Ice, G.G. and Jackson, C.R. (2009) Linkages between Forest Soils and Water Quality and Quantity. Forest Ecology and Management, 258, 2269-2281.

[38] Ministry of Forests, B.C. (2001) Soil Conservation Guidebook, 2nd ed. For. Prac. Br., Min. For., Victoria, B.C. Forest Practices Code of British Columbia Guidebook. https://www2.gov.bc.ca/assets/gov/farming-natural-resources-and-industry/forestry /silviculture/silviculture-surveys/soilsurv1-23.pd

[39] Butler, K.F. and Koontz, T.M. (2005) Theory and Practice: Implementing Ecosystem Management Objectives in the USDA Forest Service. Environmental Management, 35, 138-150.

[40] Rasmussen, D.W. (1982) History of Soil Conservation, Institutions and Incentives. In: Halcrow, H.G., Heady, E.O. and Cotner, M.L., Eds., Soil Conservation Policies Institutions and Incentives, Soil Conservation Society of America, Iowa, 3-18.

[41] Showers, K.B. (2006) Soil Erosion and Conservation: An International History and a Cautionary Tale. In: Warkentin, B.P., Ed., Footprints in the Soil, People and Ideas in Soil History, Elsevier Science, Amsterdam, 369-406.

[42] Reed, M.S., Fazey, I., Stringer, L.C., Raymond, C.M., Akhtar-Schuster, M., Begni, G., Bigas, H., Brehm, S., Briggs, J., Bryce, R., Buckmaster, S., Chanda, R., Davis, J., Diez, E., Essahli, W., Evely, A., Geeson, N., Hartmann, I., Holden, J., Hubacek, K., Loris, A.A.R., Kruger, B., Laureano, P., Phillipson, J., Prell, C., Quinn, C.H., Reeves, A.D., Seely, M., Thomas, R., Van der Werff Ten Bosch, M.J., Vergunst, P. and Wagner, L. (2013) Knowledge Management for land Degradation Monitoring and Assessment: An Analysis of Contemporary Thinking. Land Degradation \& Development, 24 307-322. https://doi.org/10.1002/ldr.1124

[43] Chasek, P., Safriel, U., Shikongo, S. and Futran Fuhrman, V. (2015) Operationalizing Zero Net Land Degradation: The Next Stage in International Efforts to Combat Desertification? Journal of Arid Environments, 112, 5-13. https://doi.org/10.1016/j.jaridenv.2014.05.020 